\title{
Modification and Testing of Wind Turbine with Double Savonius
}

\author{
A. M. Shiddiq Yunus ${ }^{1, a}$, Adhe Wahdah ${ }^{1, b}$ and Ulfa ${ }^{1}$ \\ ${ }^{1}$ Mechanical Engineering Department, State Polytechnic of Ujung Pandang, Jalan Perintis Kemerdekaan KM. 10 \\ Makassar 90245, Indonesia \\ a shiddiq@poliupg.ac.id \\ b adhe_wahdah@yahoo.com
}

\begin{abstract}
Indonesia geographically located at tropical region where the wind is very fluctuate and relatively slow. Therefore it is important for designer to investigate the proper design of the slow wind speed turbine that applicable in Indonesia. In this paper, Savonius wind turbine is selected and modified with double level to explore its capability in generating voltage. The main aim of this study is to investigate the performance of the double Savonius turbine in term of its capability in generating voltage. In experimental test, it can be obtained that the double Savonius Turbine could effectively generate $12 \mathrm{~V}$ at $3 \mathrm{~m} / \mathrm{s}$ and $17 \mathrm{~V}$ at $5.4 \mathrm{~m} / \mathrm{s}$.
\end{abstract}

Keywords-Double Turbine; Savonius and Wind Turbine

\section{Introduction}

Wind energy is one of clean, friendly to environment energy sources, abundantly available naturally and free to use for energy [1]. The application of wind as source of energy is started since long time ago. It was recorded that wind had been used for sail at Nil river since 5000 BC. Application on other purposes such as drilling had been introduced in Persia, Egypt and China in $7^{\text {th }}$ Century and its application as electric power source was boomed at the beginning of $19^{\text {th }}$ century in Europe [2].

According to [3], wind characteristic in Indonesia varies from $2.7-4.5 \mathrm{~m} / \mathrm{s}$ where it is categorized as low wind speed with common turbulence. One of wind turbine type is Vertical Wind Turbine (VWT), where the main rotor is located perpendicularly. The main advantage of VWT is that no vane or tail is required to direct the turbine on wind direction. This function is very suitable for the area where the wind direction is changing rapidly. One of VWT turbine that is well known widely is Savonius. This wind turbine type is applicable on low speed wind because it could produce sufficient torque [4]. To improve the capability of Savonius in extracting energy from the wind, double Savonius is introduced in this paper to investigate the performance of the turbine in generating voltage. Typical model of Savonius is shown in Figure 1.

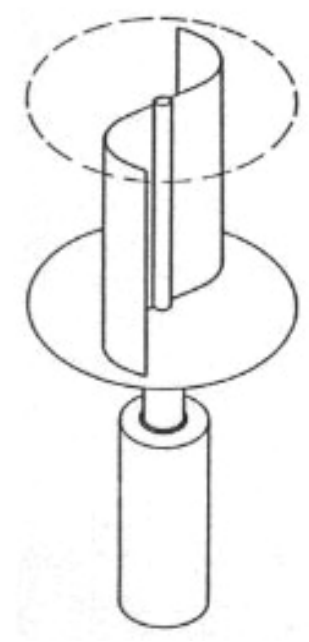

Figure 1. Typical model of Savonius

Savonius type was introduced first by Sigurd J. Savonius in 1922, an Finlandia Engineer. This turbine is a drag type where the energy is produced simply by harnessing the drag force that is opposite direction with the blades [5].

The fundamental equation used for wind energy extraction is: 


$$
P=-
$$

\section{B. Double Savonius Design}

The stage of design can be seen in Figure 2. The layout of double Savonius is shown in Figure 3.

Where:

$P$ is Generated Power (W),

$\rho$ is air density $\left(\mathrm{kg} / \mathrm{m}^{3}\right)$,

A is swipe area in $\left(\mathrm{m}^{2}\right)$,

$v$ is wind velocity in $\mathrm{m} / \mathrm{s}$.

\section{Research Methodology}

\section{A. Location and Research Time}

The data was collected at Tanjung Merdeka Beach, Tamalate District, Makassar, Indonesia. The data was collected from $27^{\text {th }}$ to $30^{\text {th }}$ September 2015 , started from 08.30 to 18.30 Center Time of Indonesia (CTI).

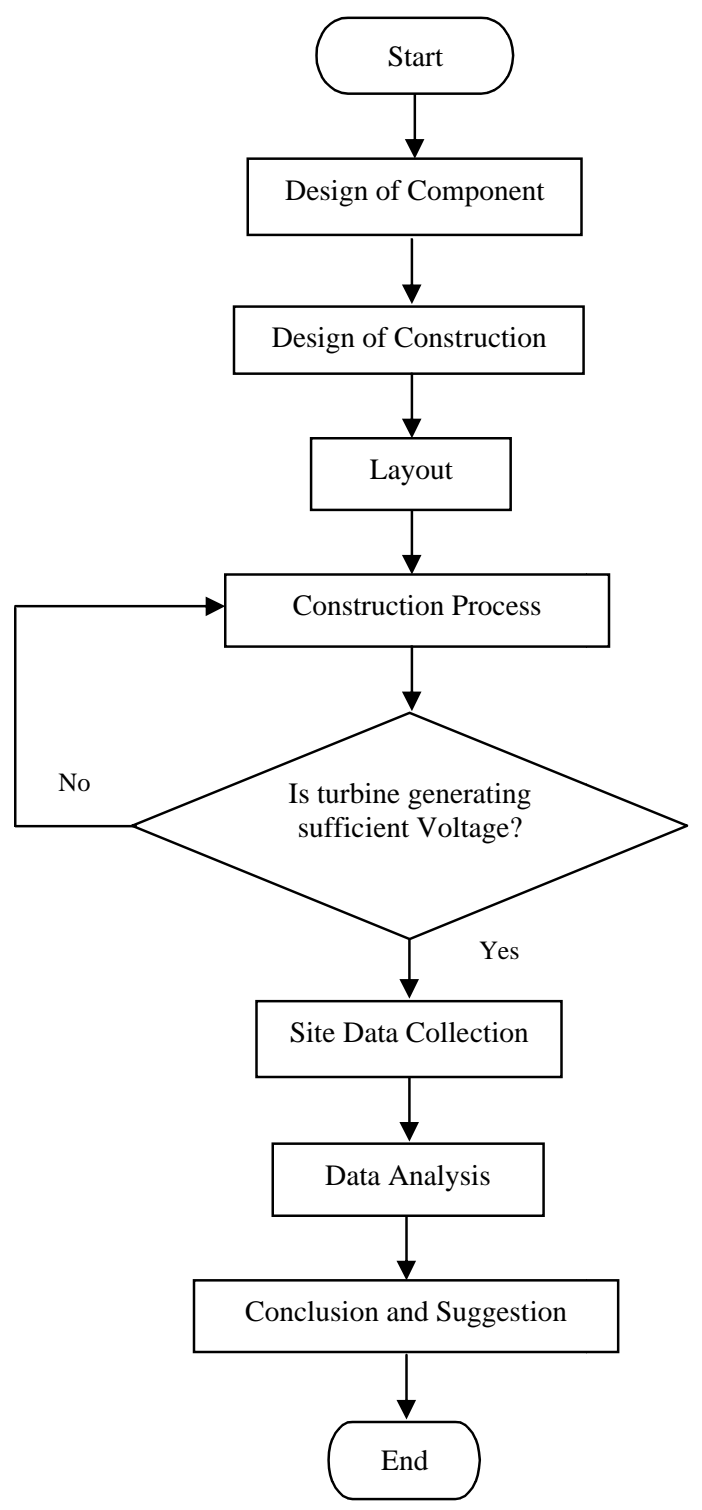

Figure 2. Research Stages
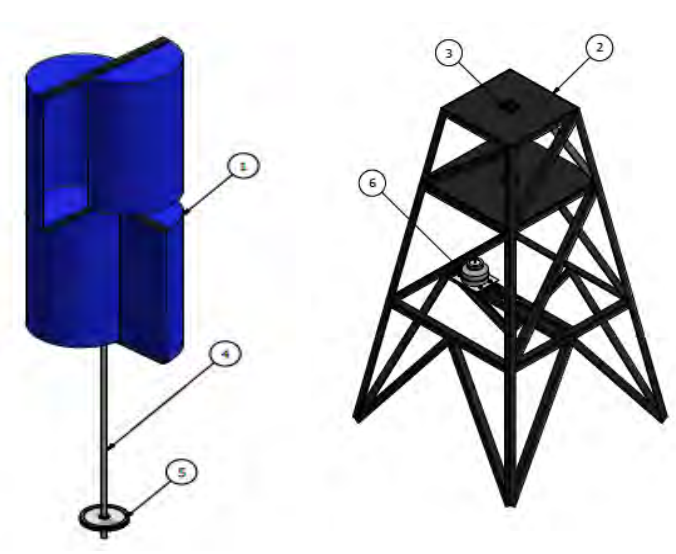

Figure 3. Design layout of the double Savonius Where:

1. Turbine's Blades

2. Turbine's Support

3. Bearing

4. Turbine's Shaft

5. Pulley

6. Generator

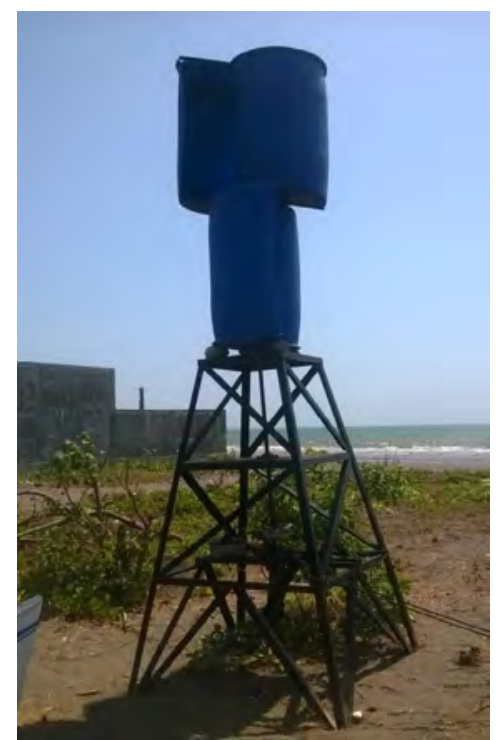

Figure 4. Real construction of the double Savonius 


\section{Results and Discussion}

The dimension of the designed double Savonius can be described in Table 1.

Table 1. Dimension Information of Designed Turbine

\begin{tabular}{|c|c|}
\hline Blades & \\
\hline a. Head & $180 \mathrm{~cm}$ \\
\hline b. Diameter & $82.5 \mathrm{~cm}$ \\
\hline \multicolumn{2}{|l|}{ Support } \\
\hline a. Head & $200 \mathrm{~cm}$ \\
\hline b. Wide & $120 \mathrm{~cm}$ \\
\hline \multicolumn{2}{|l|}{ Shaft } \\
\hline a. Diameter & $2.1 \mathrm{~cm}$ \\
\hline b. Shaft Lenght & $310 \mathrm{~cm}$ \\
\hline \multicolumn{2}{|l|}{ Pulley } \\
\hline a. Diameter & $23 \mathrm{~cm}$ \\
\hline \multicolumn{2}{|l|}{ Bearing } \\
\hline a. Diameter & $2.1 \mathrm{~cm}$ \\
\hline $\begin{array}{l}\text { Rated V: Generator AC } 1 \\
\text { Phase }\end{array}$ & $220 \mathrm{~V}$ \\
\hline
\end{tabular}

Tabel 2. Hasil Pengukuran Turbin Angin Savonius Tipe Tingkat

\begin{tabular}{|c|c|c|c|c|c|}
\hline No. & $\begin{array}{c}\text { Wind } \\
\text { Speed } \\
(\mathrm{m} / \mathrm{s})\end{array}$ & $\begin{array}{c}\mathrm{N}_{\text {generator }} \\
(\mathrm{Rpm})\end{array}$ & $\begin{array}{c}\text { Charging } \\
\text { Voltage } \\
(\mathrm{V})\end{array}$ & $\begin{array}{c}\text { Phase } \\
\text { Voltage } \\
(\mathrm{V})\end{array}$ & $\begin{array}{c}\text { Measured } \\
\text { Current } \\
(\mathrm{A})\end{array}$ \\
\hline 1 & 3.2 & 41 & 13 & 14 & 0.02 \\
\hline 2 & 3.2 & 49 & 12 & 13 & 0.03 \\
\hline 3 & 3.2 & 53 & 12 & 13 & 0.03 \\
\hline 4 & 3.4 & 65 & 13 & 14 & 0.03 \\
\hline 5 & 3.7 & 66 & 13 & 15 & 0.04 \\
\hline 6 & 3.8 & 74 & 14 & 15 & 0.05 \\
\hline 7 & 3.6 & 75 & 14 & 17 & 0.06 \\
\hline 8 & 3.4 & 79 & 14 & 17 & 0.07 \\
\hline 9 & 3.8 & 80 & 13 & 15 & 0.08 \\
\hline 10 & 4.2 & 87 & 15 & 19 & 0.09 \\
\hline 11 & 3.5 & 95 & 15 & 19 & 0.08 \\
\hline 12 & 4 & 99 & 14 & 18 & 0.14 \\
\hline 13 & 4.2 & 102 & 14.5 & 18 & 0.1 \\
\hline 14 & 4 & 103 & 14 & 19 & 0.12 \\
\hline 15 & 4.1 & 106 & 15 & 20 & 0.06 \\
\hline 16 & 5 & 115 & 14 & 20 & 0.14 \\
\hline 17 & 5 & 118 & 15 & 23 & 0.12 \\
\hline 18 & 5.5 & 123 & 16 & 23 & 0.18 \\
\hline
\end{tabular}

Table 2 shows the performance of the double Savonius in terms of generated voltage in accordance to wind speed.
The performance of the testing stage of the double Savonius can be seen in Figure 5 to 9.

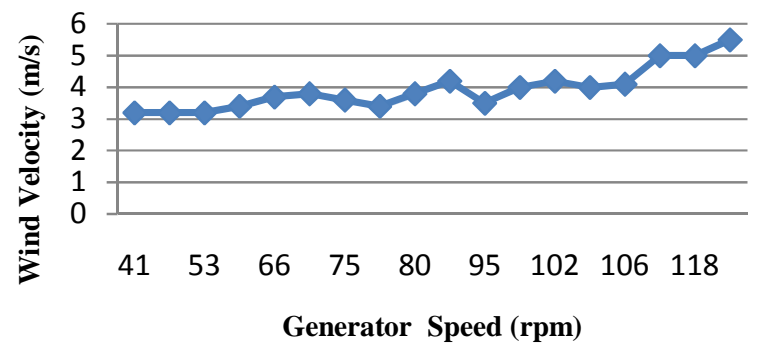

Figure 5. Trend of wind speed vs generator speed

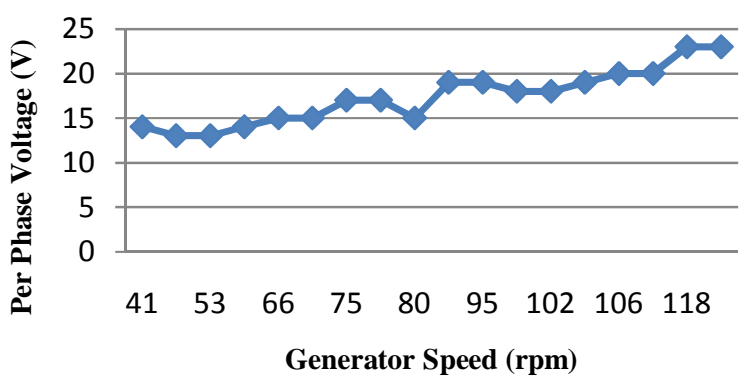

Figure 6. Trend of per-phase vs generator speed

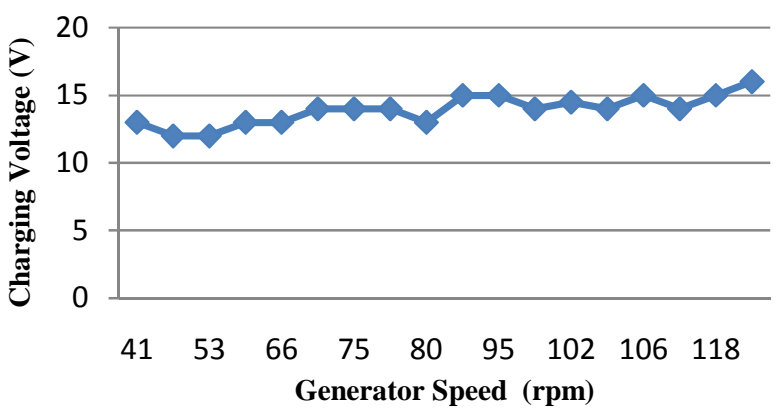

Figure 7. Charging phase vs generator speed

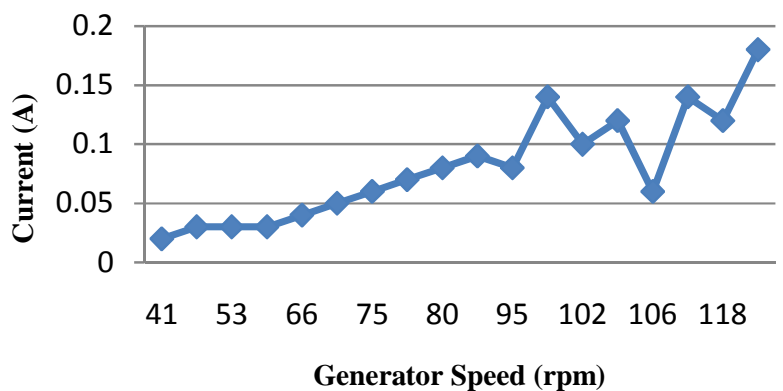

Figure 8. Current vs generator speed 


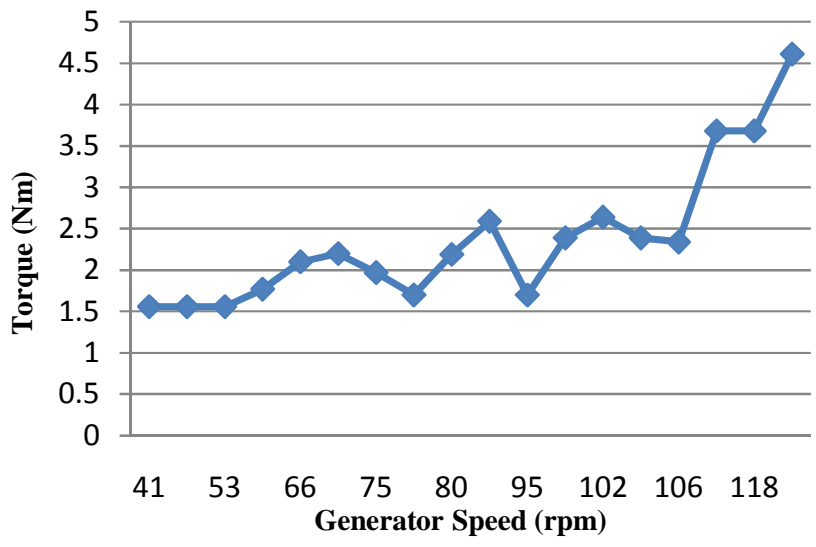

Figure 9. Current vs generator speed

It can be seen from Figure 5 to 9 that when wind speed increased, the other parameters are also raised gradually. It was measured that starting point of this double Savonius could generate voltage is $3 \mathrm{~m} / \mathrm{s}$ and resulting about $12 \mathrm{~V}$ whilst the maximum voltage could be generate is $17 \mathrm{~V}$ at the wind speed of $5.4 \mathrm{~m} / \mathrm{s}$. The small fluctuation occurs due to the fact that data was taken per hour and not in continuous ways. It can be seen in Table 2 that some wind speed values have the same values but in rpm measurement come with small differences. This occurs due to the fact that wind speed intermittently influences the starting torque of the double Savonius. For simplicity of analysis, data that was collected in 4 days is sorted from the lowest to the highest wind speed.

\section{Conclusion}

From the testing results, it can be concluded that double Savonius could generate about minimum $12 \mathrm{~V}$ at speed of $3.0 \mathrm{~m} / \mathrm{s}$ and maximum 17 Volt at $5.4 \mathrm{~m} / \mathrm{s}$. With minimum $12 \mathrm{~V}$ of charging voltage it is sufficient to charge an accu after rectifying.

\section{Acknowledgement}

Authors would like to thanks State Polytechnic of Ujung Pandang in accordance with Center of Sustainable Energy and Smart Grid Application (COSESGA), Mechanical Engineering Department for the research support funding through DIPA Scheme.

\section{References}

[1] Nakajima, M., Lio, S., dan Ikeda, T., 2008. Performance of Savonius Rotor for Environmentally Friendly Hidroulic Turbine. Journal of Fluid Science And Technology. Volume 3 No. 3, pp 420-429

[2] Ajao, K.R., dan Mahamood, M.R., 2009. Wind Energy Conversion System The Past, The Present And The Prospect, Journal of American Science, (Online), Volume 5, No. 6, pp 17-22 (diakses 1 April 2015).

[3] Daryanto, Y., 2005. Kajian Potensi Angin Untuk Pembangkit Listrik Tenaga Bayu. Balai PPTAGG http://www.kurniadinews.com/makalah-listrik/potensi-tenagaangin-di-indonesia/ - UPT-LAGG

[4] J. Sargolzaei. 2007. Prediction Of The Power Ratio In Wind Turbine Savonius Rotor Using Artificialneural Networks. International Juornal Of Energi and Environment

[5] White, Frank M. 1986. Fluid mechanics, mcGraw Hill Book Company. New york 